\title{
Towards the gemini cation anion exchange membranes by nucleophilic substitution reaction
}

\author{
Jianjun Zhang ${ }^{\dagger}$, Yubin $\mathrm{He}^{\dagger}$, Xian Liang, Xiaolin Ge, Yuan Zhu, Min Hu, Zhengjin Yang, \\ Liang $\mathrm{Wu}^{*}$ and Tongwen $\mathrm{Xu}^{*}$
}

\begin{abstract}
As a critical component of alkaline fuel cells, anion exchange membranes determine the energy efficiency, output power density and the long term stability. Recently, the anion exchange membranes with gemini-cation side chains exhibit superior ion conductivity due to their good nanophase separation. However, the costly and complicated synthesis limits their scaling up and commercialization. To address this problem, a convenient synthetic procedure under mild conditions is well developed. A tertiary amine precursor is introduced onto the polymer by the nucleophilic substitution reaction to avoid the conventional chloro/bromo-methylation. Followed by a simple Menshutkin reaction with 6bromo- $N, N, N$-trimethylhexan-1-aminium bromide, the polymer electrolytes are obtained in a high yield. The resulting anion exchange membranes with high conductivity, good fuel cell performance and restricted swelling suggest the potential for the application in fuel cell devices.
\end{abstract}

Keywords: anion exchange membranes, fuel cell, nucleophilic substitution reaction, nano-phase separation

\section{INTRODUCTION}

Fuel cell is a kind of electrochemical devices which can directly convert chemical energy into electrical energy in a highly efficient and environmentally friendly manner. Among the various types of fuel cells, proton exchange membrane fuel cell (PEMFC) which adopts a proton exchange membrane as the ion conductor and gas separator has promising potential as the next-generation of energy-converting device due to its inherent advantages such as high current density and low working temperature [1-3]. However, because of the lower oxygen reduction kinetics in the acidic environment, only precious metal catalyst like Pt can ensure the cathode catalytic activity [4]. This evokes the development of anion exchange membrane fuel cell (AEMFC). By employing an anion exchange membrane (AEM) instead of proton exchange membrane (PEM), the oxygen reduction on the cathode can perform in basic environment and thus non-precious metal catalyst like $\mathrm{Ni}$ and $\mathrm{Ag}$ can be used [5]. Besides, in contrast to the PEMFC, the hydrated $\mathrm{OH}^{-}$in an AEMFC transport from the cathode to the anode, which simplifies the water management [6].

As a fundamental component of AEMFC, AEMs should be highly conductive for high power density. In the past decades, much research has focused on the AEM materials to improve the hydroxide conductivity [7-11]. Generally, the relationship between polymer structure and membrane conductivity is elucidated by the phase separation theory [12]. When a hydrophilic segment and a hydrophobic segment are contained in the same polymer chain, the resulting polarity discrimination will lead to the phase-separation in nanoscale. The hydrophilic phase with a high density of ion conducting groups is considered the main pathway for the $\mathrm{OH}^{-}$transport, namely the ion conducting channels.

Conventional AEMs are prepared by closely attaching the quaternary ammonium groups onto the polymer backbones. This leads to a poor nano-phase separation due to the lack of hydrophilic-hydrophobic discrimination. Afterwards, a series of side chain type AEMs are developed as inspired by the commercial Nafion ${ }^{\circ}$ membranes [13-21]. A flexible spacer of 4-6 carbon atoms is introduced between the ion conducting groups and the polymer backbone. The hydrophobic main chain and the hydrated side chain can lead to the phase separated morphology. For example, Jannasch and co-

CAS Key Laboratory of Soft Matter Chemistry, Collaborative Innovation Centre of Chemistry for Energy Materials, School of Chemistry and Materials Science, University of Science and Technology of China, Hefei 230026, China

† These authors contributed equally to this work.

* Corresponding authors (emails: twxu@ustc.edu.cn (Xu T); Liangwu8@ustc.edu.cn (Wu L)) 
a

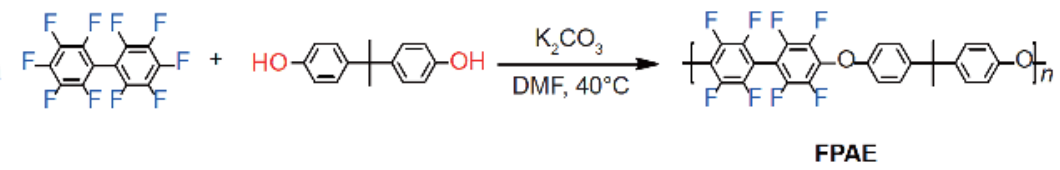<smiles>CN(C)CCc1ccc(O)cc1</smiles><smiles>CN(C)CCc1ccc(Oc2c(F)c(Oc3ccc(C(C)(C)c4ccc(C(F)(F)F)cc4)cc3)c(F)c(-c3c(F)c(F)c(F)c(F)c3F)c2F)cc1</smiles>

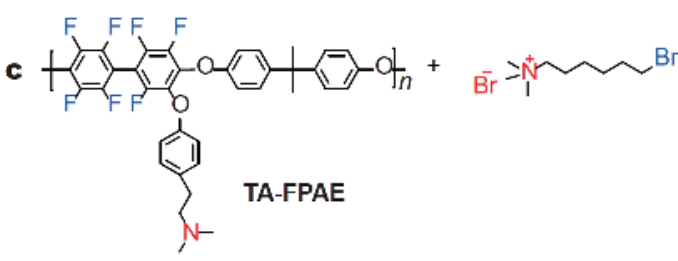<smiles>CC(C)(F)Oc1ccc(C(C)(C)c2ccc(Oc3c(F)c(F)c(-c4c(F)c(F)c(C(F)(F)F)c(F)c4F)c(F)c3Oc3ccc(CC[N+](CBr)(CBr)CCCCC[N+](C)(C)C)cc3)cc2)cc1</smiles>

Scheme 1 Synthesis of (a) FPAE polymer backbone, (b) tertiary amine containing polymer precursor, and (c) dual-cation AEM.

workers [22] synthesized a side-chain type AEM by bromoalkylation of poly(phenylene oxide) (PPO) with $n$ $\mathrm{BuLi}$ and afterwards quaternization. Ion-conducting channels with the average size of $\sim 3 \mathrm{~nm}$ were obviously observed by small angle X-ray scattering (SAXS) and the room temperature conductivity reached $33 \mathrm{mS} \mathrm{cm}^{-1}$. Another strategy to enhance the phase separation of AEMs is to densely functionalize one particular unit of the polymer chain. The resulting ion cluster can easily aggregate to form ion conducting channels [23-26]. For example, Wang and co-workers [27] reported AEM with five quaternary ammonium groups on the same phenyl ring. This densely functionalized AEM exhibits an obvious phase separated morphology and good hydroxide conductivity of $50 \mathrm{mS} \mathrm{cm}^{-1}$ at $80^{\circ} \mathrm{C}$.

To further enhance the AEM conductivity, researchers have developed AEMs with densely functionalized side chains [28-33]. Generally, a functional side chain with a tertiary amine group and a quaternary ammonium group (TAC6QA) was synthesized via the reaction between $N, N, N^{\prime}, N^{\prime}$-tetramethyl-1,6-hexanediamine (TMHDA) and haloalkanes. After the Menshutkin reaction with bromo/ chloro-methylated polymers, AEM was functionalized by a gemini-cation side chain. As a combination of the side chain type AEM and the densely functionalized AEM, better nano-phase separation and increased $\mathrm{OH}^{-}$conductivity were observed due to the enhanced side chain hydropholicity. However, for synthesizing TAC6QA, excess TMHDA is required and the separation of the products from the by-product and starting material is complicated, which is not suitable for scaling up and commercialization. Thus in this study, a convenient synthetic procedure was developed.

The most frequently adopted method to introduce ion conducting groups onto the AEM backbone is the Menshutkin reaction between the bromo/chloro-methylated polymer precursor and the tertiary amine [34-38]. However, the chloro-methylation depends on the highly toxic chloromethyl ether while the free radical bromination complicates side reactions like branching, crosslinking, and chain scission [39].

To avoid these disadvantages, the aromatic nucleophilic substitution reaction, which is generally adopted for synthesizing the AEM backbones like polyethersulfone (PES) and polyetherketone (PEK), is employed to introduce the gemini cation side chains. As depicted in Scheme 1, hordenine containing phenol groups and tertiary amine groups are chosen as the nucleophile to react with the fluorinated polyaryleneether (FPAE). The resulting tertiary amine precursor further reacted with 
6-bromo- $N, N, N$-trimethylhexan-1-aminium bromide (BrC6QA) to obtain the gemini cation side chains. The polymer product of each step could be easily purified by precipitating in non-solvent and the BrC6QA could be prepared from dibromohexane and trimethyl amine in quantitative yield. The resulting AEMs were firstly investigated by the atomic force microscope (AFM) to confirm their nano-phase separated morphology. Hydroxide conductivity and fuel cell performance were measured to demonstrate the advantage of this design.

\section{EXPERIMENTAL SECTION}

\section{Materials}

Perfluorobiphenyl, bi-phenol A, dibromohexane, $\mathrm{Cs}_{2} \mathrm{CO}_{3}$ and hordenine were purchased from Energy Chemical Co. Ltd. and used as received. $\mathrm{N}, \mathrm{N}$-dimethylformamide (DMF, AR), tetrahydrofuran (THF), ether, ethanol, chloroform, trimethylamine aqueous solution (33\%), hydrochloric acid $(\mathrm{HCl})$ aqueous solution (37\% AR), sodium chloride (AR), sodium hydroxide (AR) and sodium sulfate $\left(\mathrm{Na}_{2} \mathrm{SO}_{4}, \mathrm{AR}\right)$ were purchased from Sinopham Chemical Reagent Co. Ltd. Deionized water was used throughout.

\section{Synthesis of FPAE}

Perfluorobiphenyl $(7.3179 \mathrm{~g})$, bi-phenol A (5 g) and $\mathrm{K}_{2} \mathrm{CO}_{3}(10 \mathrm{~g})$ were mixed and reacted in $40 \mathrm{~mL}$ DMF at $40^{\circ} \mathrm{C}$ under $\mathrm{N}_{2}$ atmosphere. After $24 \mathrm{~h}, 1 \mathrm{~g}$ perfluorobiphenyl was added and the solution was stirred at $60^{\circ} \mathrm{C}$ for another $24 \mathrm{~h}$. Afterwards, the resulting solution was poured into excess water and filtrated. After dried at $60^{\circ} \mathrm{C}$ for $24 \mathrm{~h}$, the polymer was redissolved by $\mathrm{CHCl}_{3}$ and precipitated in methanol. After filtration and dried at $60^{\circ} \mathrm{C}$, white polymer product was obtained and named as FPAE (yield=95\%). Nuclear magnetic resonance (NMR) spectrum of FPAE was recorded using $\mathrm{CDCl}_{3}$ as the solvent.

\section{Synthesis of BrC6QA}

BrC6QA was synthesized according to our previous literature [33]: a stirring solution of dibromohexane $(10 \mathrm{~mL})$ in THF $(100 \mathrm{~mL})$ was continuously bumbled dry trimethylamine gas at ambient temperature and pressure for $3 \mathrm{~h}$. Afterwards, the reaction mixture was stirred at room temperature for $48 \mathrm{~h}$. The white precipitate was collected by filtration and washed with ether followed by being dried in vacuum for $48 \mathrm{~h}$ (yield=92\%). NMR spectrum of BrC6QA was obtained with $\mathrm{D}_{2} \mathrm{O}$ as solvent.

\section{Synthesis of tertiary amine functionalized FPAE (TA- FPAE)}

The grafting ratio of tertiary amine was controlled by the amount of hordenine. The synthetic procedure of TAFPAE- 4 is described here: FPAE $(0.5 \mathrm{~g})$, hordenine $(0.3 \mathrm{~g})$ and $\mathrm{Cs}_{2} \mathrm{CO}_{3}(1.0 \mathrm{~g})$ was added to $20 \mathrm{~mL}$ DMF. The reaction mixture was heated to $100^{\circ} \mathrm{C}$ and stirred under $\mathrm{N}_{2}$ atmosphere for $24 \mathrm{~h}$. The TA-FPAE was obtained by precipitating into water and washed with ether. NMR spectrum of BrC6QA was recorded using $\mathrm{CDCl}_{3}$ as the deuterated solvent.

\section{Synthesis of gemini cation functionalized FPAE (BQA-} FPAE)

TA-FPAE $(0.5 \mathrm{~g})$ and BrC6QA (1.25 equiv) was dissolved in $15 \mathrm{~mL}$ of DMF. The reaction mixture was heated to $60^{\circ} \mathrm{C}$ and stirred for $24 \mathrm{~h}$. The resulting solution was precipitated in ether and washed with $\mathrm{CHCl}_{3}$. After dried in vacuum at room temperature for $24 \mathrm{~h}, \mathrm{BQA}-\mathrm{FPAE}$ was obtained and characterized by NMR using DMSO- $\mathrm{d}_{6}$ as the deuterated solvent. AEM of BQA-FPAE can be obtained by casting onto a glass plate and dried at $80^{\circ} \mathrm{C}$ for $4 \mathrm{~h}$.

\section{Characterizations}

${ }^{1} \mathrm{H}$ NMR spectra was performed with an AV III 400 NMR spectrometer $\left({ }^{1} \mathrm{H}\right.$ resonance at $400 \mathrm{MHz}$, Bruker). Tapping mode atomic force microscopy (AFM) was recorded by a Veeco diinnova SPM. Tensile strength and elongation at break of the membranes were measured using a Q800 dynamic mechanical analyser (DMA, TA Instruments) at a stretch rate of $0.5 \mathrm{~N} \mathrm{~min}^{-1}$ under air atmosphere. Thermal stability of the membrane was characterized by a Q5000 thermo-gravimetric analyzer (TGA, TA Instruments) under $\mathrm{N}_{2}$ flow with a temperature increase rate of $10^{\circ} \mathrm{C} \mathrm{m^{-1 }}$. Water uptake, swelling, ion exchange capacity [40], conductivity [33] and fuel cell performance [41] were measured according to our previous literatures.

\section{RESULTS AND DISCUSSION}

\section{Synthesis and NMR characterization}

An ideal synthetic procedure for AEM should be convenient and performed under mild conditions. Thus in this study, the highly efficient nucleophilic substitution reaction and Menshutkin reaction were selected. The products of each step were obtained in a high yield and purified by a simple process. As the main advantage of this design, the adoption of chloro/bromo-methylated 


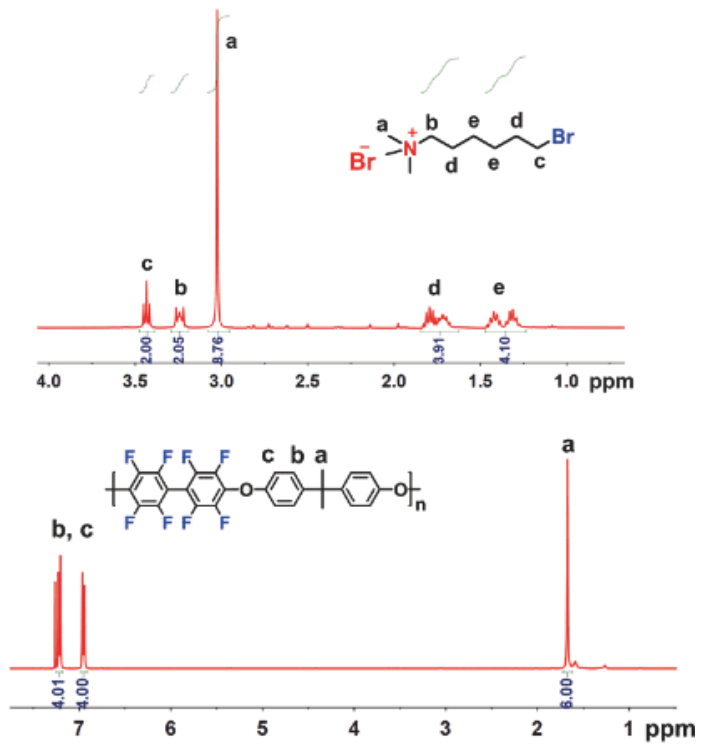

Figure $1{ }^{1} \mathrm{H}$ NMR spectra of FPAE (below) and BrC6QA (upper).

polymers was avoided by developing a polymer precursor with tertiary amines. Firstly, FPAE was polymerized from the perfluorobiphenyl and bi-phenol A for $24 \mathrm{~h}$ below $40^{\circ} \mathrm{C}$. Then, excess perfluorobiphenyl was added to avoid polymeric crosslinking/branching between fluoro-benzene and terminal hydroxyl groups. After $24 \mathrm{~h}$ reaction, the polymeric product was obtained by precipitating the reaction mixture in methanol. As depicted in Fig. 1, the chemical structure of FPAE was well confirmed by ${ }^{1} \mathrm{H}$ NMR. The remaining fluoride groups were utilized as the electrophiles to react with the hordenine to introduce tertiary amine groups. The adding amount of hordenine was controlled to obtain different grafting ratio of tertiary amine groups. As an example, the ${ }^{1} \mathrm{H}$ NMR spectrum of TA-FPAE-4 is depicted in Fig. 2. Signal $\mathrm{f}$ at $2.26 \mathrm{ppm}$ is assigned to the protons of $-\mathrm{N}-\mathrm{CH}_{3}$ group. The signals for protons from $-\mathrm{CH}_{2}-\mathrm{CH}_{2}-\mathrm{N}-$ groups appear around $2.50 \mathrm{ppm}$. BrC6QA was synthesized in the tetrahydrofuran (THF) at room temperature to graft the gemini cation side chain from the tertiary amine precursor. Because of the insolubility in THF, BrC6QA was precipitated from the solution before another bromide group was converted to quaternary ammonium group, and thus highly pure BrC6QA could be obtained by the filtration without further purification. Lastly, BrC6QA reacted with TA-FPAE- 4 at $60^{\circ} \mathrm{C}$ to obtain BQA-FPAE-4. The gemini-cation AEM could be obtained by directly casting the polymer solution. For NMR characterization, the above mentioned polymer solution was poured in ether and washed with dichloromethane. The signals of the

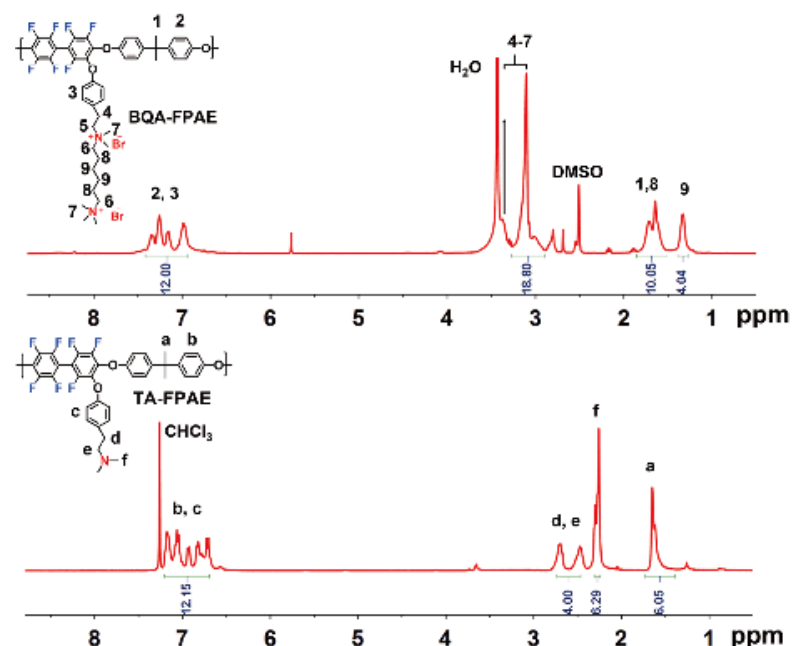

Figure $2{ }^{1} \mathrm{H}$ NMR spectra of TA-FPAE-4 (below) and BQA-FPAE-4 (upper).

tertiary amine disappeared while a new signal of quaternary ammonium group at $3.1 \mathrm{ppm}$ was observed. Based on the integral ratio of signal 2, 3 and signal 9, it was calculated that $\sim 1.0$ side chain was grafted onto one repeat unit of polymer backbones for BQA-FPAE-4 membranes. This is consistent with the value (1.0) calculated based on the ion exchange capacity.

\section{Phase separation and hydroxide conductivity}

As elucidated in the introduction section, the purpose of introducing the gemini cation side chain is to facilitate the formation of phase separated morphology. This design can combine the 'group mobility' of side chain type AEMs and the 'group density' of the densely functionalized AEMs. The AFM images of BQA-FPAE4 AEM (Fig. 3) show that the phase image exhibits distinctly different pattern from the height image. As depicted in Fig. 3, the bright regions represent the phase of aromatic main chain while the dark regions represent the hydrophilic ion conducting channels. The welldefined phase separated morphology of BQA-FPAE-4 was mainly attributed to the hydropholicity discrimination between the fluorinated main chain and the ionic side chains [42-46].

To further demonstrate the advantage of this design, the hydroxide conductivity of the prepared AEMs was measured and depicted in Fig. 4. Since the counter-ions in AEM might be gradually converted to $\mathrm{HCO}_{3}{ }^{-}$by utilizing air as the oxidant, the conductivity of AEMs was measured in the $\mathrm{OH}^{-}$and $\mathrm{HCO}_{3}^{-}$form. As depicted in Fig. 4, the conductivity of $\mathrm{OH}^{-}$and $\mathrm{HCO}_{3}{ }^{-}$increased with 


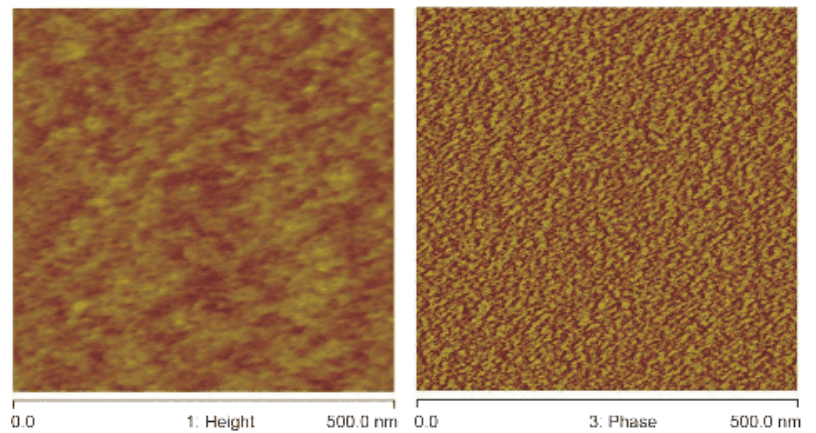

Figure 3 AFM height image and phase image of the BQA-FPAE-4 membrane.

ion exchange capacity (IEC). BQA-FPAE-4 membrane with IEC of $1.95 \mathrm{mmol} \mathrm{g}^{-1}$ shows the $\mathrm{OH}^{-}$conductivity of $33.6 \mathrm{mS} \mathrm{cm}^{-1}$ and $\mathrm{HCO}_{3}^{-}$conductivity of $12 \mathrm{mS} \mathrm{cm}{ }^{-1}$. It is reported that the mobility of $\mathrm{OH}^{-}$in the aqueous solution is around 5 times higher than that of $\mathrm{HCO}_{3}{ }^{-}$ [47]. John and co-workers [48] once calculated the $\mathrm{OH}^{-}$ conductivity from $\mathrm{HCO}_{3}{ }^{-}$conductivity by a 3.8 multiplication factor. In this study, the $\mathrm{OH}^{-}$conductivity of BQA-FPAE-4 is only 2.8 times higher than that of $\mathrm{HCO}_{3}{ }^{-}$. As shown in Fig. 4, the $\mathrm{OH}^{-}$conductivity increases from 33 to $67 \mathrm{mS} \mathrm{cm}^{-1}$ with temperature increasing from room temperature to $80^{\circ} \mathrm{C}$. Notably, the $\mathrm{HCO}_{3}{ }^{-}$conductivity reaches up to $50 \mathrm{mS} \mathrm{cm}{ }^{-1}$ at $80^{\circ} \mathrm{C}$, which is 4.2 times higher than that at room temperature. This phenomenon might be explained by the lower water uptake (42.7\%) of BQA-FPAE-4 because the $\mathrm{OH}^{-}$ conduction is dependent on the hydrogen bonds between ions and water.

Water uptake and swelling ratio

Water uptake and swelling mainly depend on the ion

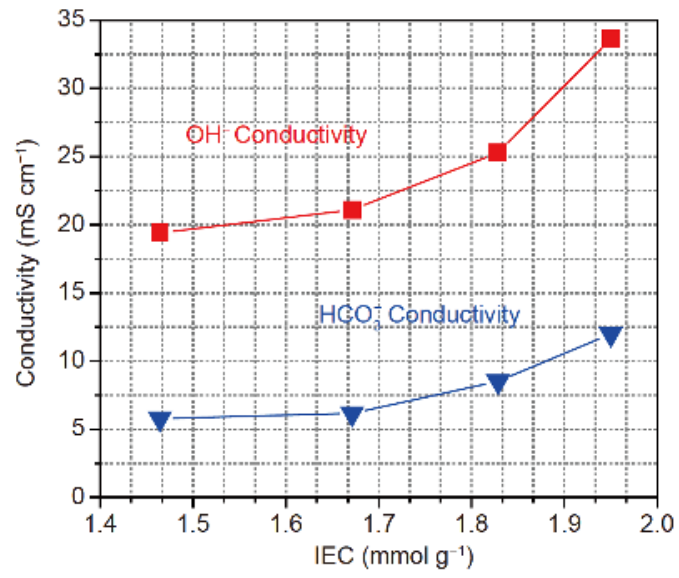

exchange capacity of AEMs. Generally, high IEC is beneficial to achieving high conductivity while leads to undesired loss of dimensional stability. There are some strategies that restrict the swelling of membranes such as crosslinking [28,46,49,50] and introducing hydrophilic moieties [51,52]. Besides, the phase separated morphology could also restrict the excess absorption of water due to the well-connected hydrophobic network. In this study, the fluorinated main chain and the good nanophase separation resulting from the gemini cation side chain can synergistically decrease the water uptake and swelling ratio of membranes. As a result, the BQA-FPAE membrane with IEC values of $1.95 \mathrm{mmol} \mathrm{g}^{-1}$ exhibits room temperature water uptake of $42.7 \%$ and swelling ratio of $14.1 \%$. Because the AEMFC device generally works at $60-80^{\circ} \mathrm{C}$, the temperature-dependent dimensional stability of membranes was also measured. As depicted in Fig. 5, the swelling ratio just slightly increases in the temperature range from 25 to $80^{\circ} \mathrm{C}$ due to the welldeveloped phase separated morphology.

\section{Mechanical properties and thermal stability}

Similar to dimensional stability, the mechanical properties of AEMs decrease with increasing IEC due to the weakened chain entanglement caused by water absorption. To further evaluate the feasibility of this design for fuel cells, Tensile strength and elongation at the break of BQA-FPAE membranes were measured. As depicted in Table 1, BQA-FPAE-4 with the highest IEC exhibits a high tensile strength of $9.4 \mathrm{MPa}$ and an $E_{\mathrm{b}}$ of $12.8 \%$, confirming that the as-prepared AEM possesses sufficient tensile strength and suitable flexibility for fuel cells.

Thermo-gravimetric curve of BQA-FPAE-4 membrane is also presented in Fig. 6 to demonstrate its good thermal

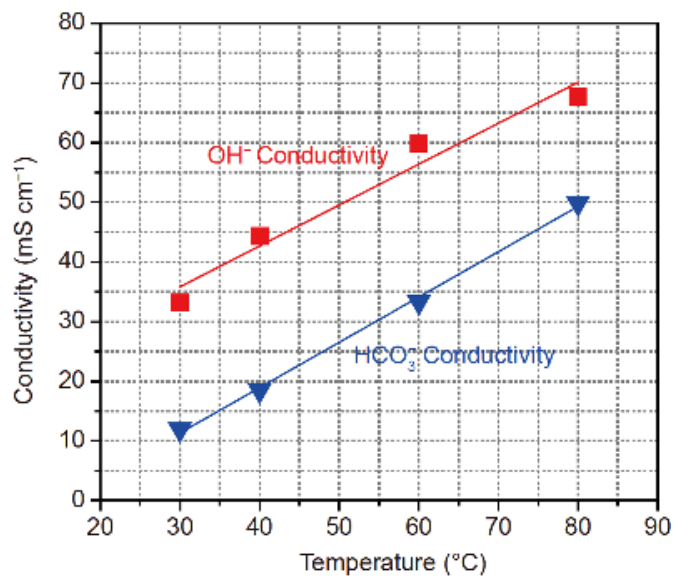

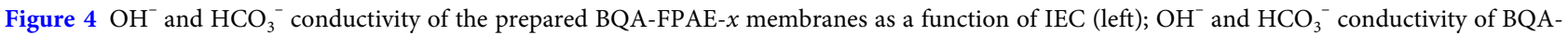
FPAE-4 membrane as a function of temperature (right). 

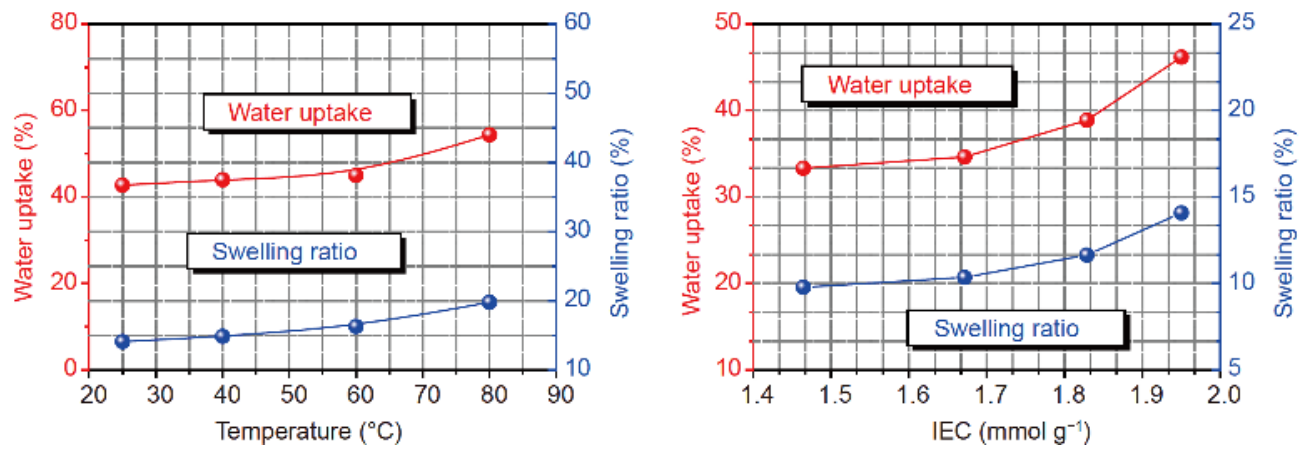

Figure 5 Water uptake and swelling ratio of prepared BQA-FPAE- $x$ membranes as a function of IEC (right) at room temperature; water uptake and swelling ratio of BQA-FPAE-4 membrane as a function of temperature (left).

Table 1 Key properties of as-prepared BQA-FPAE AEMs

\begin{tabular}{ccccccccc}
\hline Membrane & $\begin{array}{c}\mathrm{IEC}^{\mathrm{a}} \\
\left(\mathrm{mmol} \mathrm{g}^{-1}\right)\end{array}$ & $\begin{array}{c}\mathrm{IEC}^{\mathrm{b}} \\
\left(\mathrm{mmol} \mathrm{g}^{-1}\right)\end{array}$ & $\begin{array}{c}\mathrm{WU} \\
(\%)\end{array}$ & $\begin{array}{c}\text { Swelling } \\
(\%)\end{array}$ & $\begin{array}{c}\sigma_{\mathrm{OH}^{-}} \\
\left(\mathrm{mS} \mathrm{cm}^{-1}\right)\end{array}$ & $\begin{array}{c}\sigma_{\mathrm{HCO}_{3}^{-}} \\
\left(\mathrm{mS} \mathrm{cm}^{-1}\right)\end{array}$ & $\begin{array}{c}\mathrm{TS} \\
(\mathrm{MPa})\end{array}$ & $\begin{array}{c}E_{\mathrm{b}} \\
(\%)\end{array}$ \\
\hline BQA-FPAE-1 & 1.46 & 1.47 & 33.3 & 9.8 & 19.4 & 5.8 & 39.8 & 6.5 \\
BQA-FPAE-2 & 1.67 & 1.61 & 34.6 & 10.4 & 21.1 & 6.2 & 25.8 & 5.9 \\
BQA-FPAE-3 & 1.83 & 1.90 & 38.9 & 11.6 & 25.3 & 8.5 & 13.6 & 10.7 \\
BQA-FPAE-4 & 1.95 & 2.01 & 42.7 & 14.1 & 33.6 & 12.0 & 9.4 & 12.8 \\
\hline
\end{tabular}

${ }^{*}$ Ion exchange capacity $\left(\mathrm{IEC}{ }^{\mathrm{a}}\right)$, water uptake (WU), swelling raito, $\mathrm{OH}^{-}$conductivity $\left(\sigma_{\mathrm{OH}^{-}}\right)$and $\mathrm{HCO}_{3}{ }^{-}$conductivity $\left(\sigma_{\mathrm{HCO}_{3}}{ }^{-}\right)$were measured at room temperature. Tensile strength (TS) and elongation at break $\left(E_{\mathrm{b}}\right)$ were measured in hydrated state at room temperature. a) IEC was calculated by elemental analysis. b) IEC was measured by titration method.

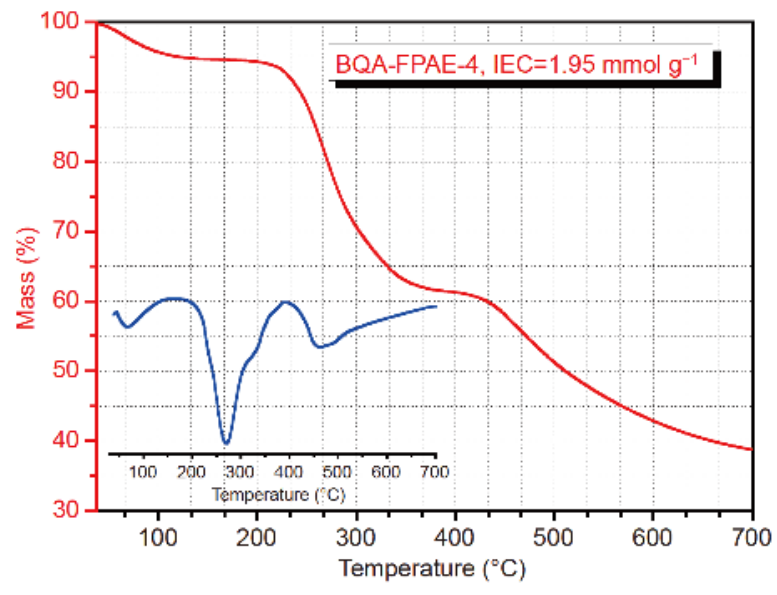

Figure 6 TGA and DTG (inset) curves of BQA-FPAE-4 membrane.

stability. The initial weight loss of $\sim 5.1 \%$ below $100^{\circ} \mathrm{C}$ is due to the loss of absorbed water. The degeneration of quaternary ammonium group starts at $187^{\circ} \mathrm{C}$. Weight loss of $\sim 33 \%$ was observed during the temperature between 187 and $390^{\circ} \mathrm{C}$, which could be ascribed to the decomposition of aliphatic side chains. After $390^{\circ} \mathrm{C}$, the polymer main chain starts to decompose. In an AEMFC device, the operation temperature is below the boiling point of water. We can conclude that the BQA-FPAE-4 membrane possesses sufficient thermal stability for fuel cells.

\section{Fuel cell performance}

Based on the above results, the prepared BQA-FPAE-4 membrane exhibits the obvious phase-separated morphology, high hydroxide conductivity, moderate swelling ratio, and good mechanical properties. The single cell performance of BQA-FPAE-4 was investigated and depicted in Fig. 7. At $50^{\circ} \mathrm{C}$ and with the catalyst loading of $0.5 \mathrm{mg} \mathrm{cm}^{-2}$, the open circuit voltage of $0.99 \mathrm{~V}$ is in the range of a typical alkaline fuel cell, suggesting the little effect of voltage drop caused by the fuel crossover. The maximum power density of $161 \mathrm{~mW} \mathrm{~cm}^{-2}$ is at a current density of $330 \mathrm{~mA} \mathrm{~cm}$, clearly demonstrating the feasibility of this design for fuel cell applications.

\section{CONCLUSIONS}

In this study, a convenient synthetic strategy to introduce the gemini-cation side chains was developed. By the nucleophilic substitution reaction, tertiary amine precursors were successfully attached onto the polymer main chain. Followed by the Menshutkin reaction with BrC6QA, AEMs with the well-developed phase separated 


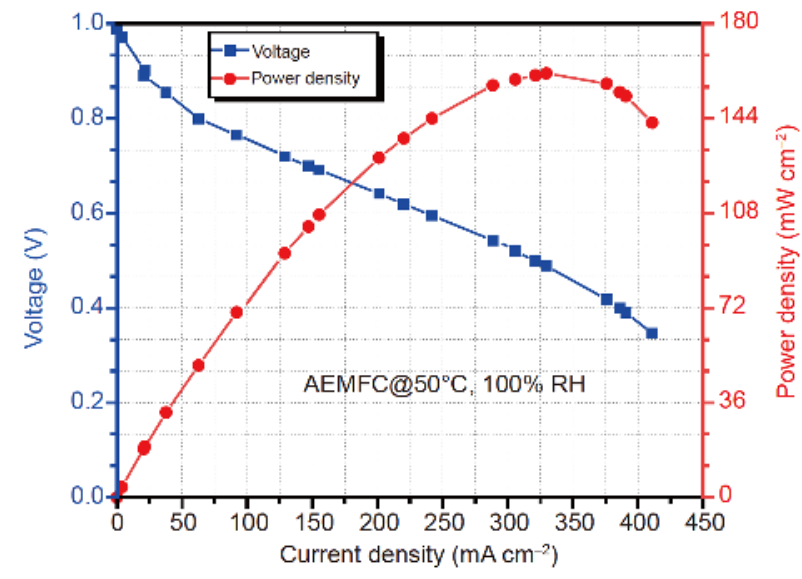

Figure 7 Fuel cell performance of selected BQA-FPAE-4 membrane.

morphology could be obtained. The reactions were performed under mild conditions and the products can be purified by simple processes. Due to the hydrophobicity of fluorinated main chains, the resulting AEMs exhibit restricted swelling ratio (14.1\%) and water uptake (42.7\%). Due to the highly hydrophilic gemini-cation side chains, the well-defined phase separated morphology and a high hydroxide conductivity $\left(33.6 \mathrm{mS} \mathrm{cm}^{-1}\right)$ were observed. As a result, a good peak power density of $161 \mathrm{~mW} \mathrm{~cm}^{-2}$ was achieved in a fuel cell device. Based on the overall consideration of the convenient synthetic procedure and good performances, this strategy holds a good potential to be scaled up and commercialized for AEMFC applications. In the future work, we will focus on developing more efficient polymer architectures based on this synthetic strategy and investigating the long-term stability in real fuel cell devices.

Received 28 November 2018; accepted 14 January 2019; published online 29 January 2019

1 Zhang $\mathrm{H}$, Shen PK. Advances in the high performance polymer electrolyte membranes for fuel cells. Chem Soc Rev, 2012, 41: 2382-2394

2 Ran J, Wu L, He Y, et al. Ion exchange membranes: New developments and applications. J Membrane Sci, 2017, 522: 267-291

3 Zakil FA, Kamarudin SK, Basri S. Modified Nafion membranes for direct alcohol fuel cells: An overview. Renew Sustain Energy Rev, 2016, 65: 841-852

4 Lu S, Pan J, Huang A, et al. Alkaline polymer electrolyte fuel cells completely free from noble metal catalysts. Proc Natl Acad Sci USA, 2008, 105: 20611-20614

5 Zakaria Z, Kamarudin SK, Timmiati SN. Membranes for direct ethanol fuel cells: An overview. Appl Energy, 2016, 163: 334-342

6 Zhang H, Shen PK. Recent development of polymer electrolyte membranes for fuel cells. Chem Rev, 2012, 112: 2780-2832

7 Chen N, Zhu H, Chu Y, et al. Cobaltocenium-containing poly- benzimidazole polymers for alkaline anion exchange membrane applications. Polym Chem, 2016, 8: 1381-1392

8 Ge X, He Y, Guiver MD, et al. Alkaline anion-exchange membranes containing mobile ion shuttles. Adv Mater, 2016, 28: 34673472

9 Zhao Y, Yu H, Xie F, et al. High durability and hydroxide ion conducting pore-filled anion exchange membranes for alkaline fuel cell applications. J Power Sources, 2014, 269: 1-6

10 Zhu L, Zimudzi TJ, Li N, et al. Crosslinking of comb-shaped polymer anion exchange membranes via thiol-ene click chemistry. Polym Chem, 2016, 7: 2464-2475

11 Zhu L, Zimudzi TJ, Wang Y, et al. Mechanically robust anion exchange membranes via long hydrophilic cross-linkers. Macromolecules, 2017, 50: 2329-2337

$12 \mathrm{Li} \mathrm{N}$, Guiver MD. Ion transport by nanochannels in ion-containing aromatic copolymers. Macromolecules, 2014, 47: 2175-2198

13 Gao L, He G, Pan Y, et al. Poly(2,6-dimethyl-1,4-phenylene oxide) containing imidazolium-terminated long side chains as hydroxide exchange membranes with improved conductivity. J Membrane Sci, 2016, 518: 159-167

14 Guo D, Lai AN, Lin CX, et al. Imidazolium-functionalized poly (arylene ether sulfone) anion-exchange membranes densely grafted with flexible side chains for fuel cells. ACS Appl Mater Interfaces, 2016, 8: 25279-25288

15 Lin CX, Huang XL, Guo D, et al. Side-chain-type anion exchange membranes bearing pendant quaternary ammonium groups via flexible spacers for fuel cells. J Mater Chem A, 2016, 4: 1393813948

16 Yan X, Gao L, Zheng W, et al. Long-spacer-chain imidazolium functionalized poly(ether ether ketone) as hydroxide exchange membrane for fuel cell. Int J Hydrogen Energy, 2016, 41: 1498214990

17 Zhang M, Liu J, Wang Y, et al. Highly stable anion exchange membranes based on quaternized polypropylene. J Mater Chem A, 2015, 3: 12284-12296

18 Zhang M, Shan C, Liu L, et al. Facilitating anion transport in polyolefin-based anion exchange membranes via bulky side chains. ACS Appl Mater Interfaces, 1944, 8: 23321-23330

19 Zuo P, Su Y, Li W. Comb-like poly(ether-sulfone) membranes derived from planar 6,12-diaryl-5,11-dihydroindolo[3,2-b]carbazole monomer for alkaline fuel cells. Macromol Rapid Commun, 2016, 37: 1748-1753

20 Zheng J, Zhang Q, Qian H, et al. Self-assembly prepared anion exchange membranes with high alkaline stability and organic solvent resistance. J Membrane Sci, 2017, 522: 159-167

21 Yang Z, Zhou J, Wang S, et al. A strategy to construct alkali-stable anion exchange membranes bearing ammonium groups via flexible spacers. J Mater Chem A, 2015, 3: 15015-15019

22 Dang HS, Weiber EA, Jannasch P. Poly(phenylene oxide) functionalized with quaternary ammonium groups via flexible alkyl spacers for high-performance anion exchange membranes. J Mater Chem A, 2015, 3: 5280-5284

23 Takaba H, Hisabe T, Shimizu T, et al. Molecular modeling of $\mathrm{OH}^{-}$ transport in poly(arylene ether sulfone ketone)s containing quaternized ammonio-substituted fluorenyl groups as anion exchange membranes. J Membrane Sci, 2017, 522: 237-244

24 Chen Y, Lin Q, Zheng Y, et al. Densely quaternized anion exchange membranes synthesized from Ullmann coupling extension of ionic segments for vanadium redox flow batteries. Sci China Mater, 2019, 62: 211-224 
$25 \mathrm{Hu} \mathrm{Y}$, Wang B, Li X, et al. Densely quaternized poly(arylene ether)s with distinct phase separation for highly anion-conductive membranes. J Power Sources, 2018, 387: 33-42

26 Weiber EA, Jannasch P. Ion distribution in quaternary-ammonium-functionalized aromatic polymers: effects on the ionic clustering and conductivity of anion-exchange membranes. ChemSusChem, 2015, 7: 2621-2630

27 Zhang W, Qiu X, Ueda M, et al. Synthesis and properties of poly (phenylene-co-arylene ether ketone)s with five quaternary ammonium groups on a phenyl unit for anion-exchange membranes. Solid State Ion, 2018, 314: 187-194

28 Han J, Zhu L, Pan J, et al. Elastic long-chain multication crosslinked anion exchange membranes. Macromolecules, 2017, 50: 3323-3332

29 He Y, Zhang J, Liang X, et al. Achieving high anion conductivity by densely grafting of ionic strings. J Membrane Sci, 2018, 559: 35-41

30 Wang J, Gu S, Xiong R, et al. Structure-property relationships in hydroxide-exchange membranes with cation strings and high ionexchange capacity. ChemSusChem, 2015, 8: 4229-4234

31 He Y, Si J, Wu L, et al. Dual-cation comb-shaped anion exchange membranes: Structure, morphology and properties. J Membrane Sci, 2016, 515: 189-195

$32 \mathrm{He} \mathrm{Y,} \mathrm{Wu} \mathrm{L,} \mathrm{Pan} \mathrm{J,} \mathrm{et} \mathrm{al.} \mathrm{A} \mathrm{mechanically} \mathrm{robust} \mathrm{anion} \mathrm{exchange}$ membrane with high hydroxide conductivity. J Membrane Sci, 2016, 504: 47-54

$33 \mathrm{He} \mathrm{Y,} \mathrm{Pan} \mathrm{J,} \mathrm{Wu} \mathrm{L,} \mathrm{et} \mathrm{al.} \mathrm{A} \mathrm{novel} \mathrm{methodology} \mathrm{to} \mathrm{synthesize} \mathrm{highly}$ conductive anion exchange membranes. Sci Rep, 2015, 5: 13417

34 Shi Q, Chen P, Zhang X, et al. Synthesis and properties of poly (arylene ether sulfone) anion exchange membranes with pendant benzyl-quaternary ammonium groups. Polymer, 2017, 121: 137148

35 Dai J, He G, Ruan X, et al. Constructing a rigid crosslinked structure for enhanced conductivity of imidazolium functionalized polysulfone hydroxide exchange membrane. Int J Hydrogen Energy, 2016, 41: 10923-10934

36 Puthiyapura VK, Mamlouk M, Pasupathi S, et al. Physical and electrochemical evaluation of ATO supported $\mathrm{IrO}_{2}$ catalyst for proton exchange membrane water electrolyser. J Power Sources, 2014, 269: 451-460

37 Hnát J, Plevová M, Žitka J, et al. Anion-selective materials with 1,4-diazabicyclo[2.2.2] octane functional groups for advanced alkaline water electrolysis. Electrochim Acta, 2017, 248: 547-555

38 Largier TD, Cornelius CJ. Random quaternary ammonium DielsAlder poly(phenylene) copolymers for improved vanadium redox flow batteries. J Power Sources, 2017, 352: 149-155

39 Yan J, Zhu L, Chaloux BL, et al. Anion exchange membranes by bromination of tetramethylbiphenol-based poly(sulfone)s. Polym Chem, 2017, 8: 2442-2449

40 He Y, Pan J, Wu L, et al. Facile preparation of 1,8-diazabicyclo [5.4.0] undec-7-ene based High performance anion exchange membranes for diffusion dialysis applications. J Membrane Sci, 2015, 491: 45-52

41 Zhu Y, He Y, Ge X, et al. A benzyltetramethylimidazolium-based membrane with exceptional alkaline stability in fuel cells: role of its structure in alkaline stability. J Mater Chem A, 2018, 6: 527-534
$42 \mathrm{Xu} \mathrm{J}$, Lin Q, Yu Y, et al. Facile synthesis of fluorinated poly(arylene ether)s with pendant sulfonic acid groups for proton exchange membranes. Int J Hydrogen Energy, 2017, 42: 27100-27110

43 Chen $\mathrm{X}$, Lü H, Lin Q, et al. Partially fluorinated poly(arylene ether)s bearing long alkyl sulfonate side chains for stable and highly conductive proton exchange membranes. J Membrane Sci, 2018, 549: 12-22

44 Chen N, Long C, Li Y, et al. A hamburger-structure imidazoliummodified silica/polyphenyl ether composite membrane with enhancing comprehensive performance for anion exchange membrane applications. Electrochim Acta, 2018, 268: 295-303

45 Chen N, Long C, Li Y, et al. High-performance layered double hydroxide/poly(2,6-dimethyl-1,4-phenylene oxide) membrane with porous sandwich structure for anion exchange membrane fuel cell applications. J Membrane Sci, 2018, 552: 51-60

46 Zhao Y, Feng L, Gao J, et al. Study on tunable crosslinking anion exchange membranes fabrication and degradation mechanism. Int J Hydrogen Energy, 2016, 41: 16264-16274

47 Varcoe JR, Atanassov P, Dekel DR, et al. Anion-exchange membranes in electrochemical energy systems. Energy Environ Sci, 2014, 7: 3135-3191

48 Deavin OI, Murphy S, Ong AL, et al. Anion-exchange membranes for alkaline polymer electrolyte fuel cells: comparison of pendent benzyltrimethylammonium- and benzylmethylimidazolium-headgroups. Energy Environ Sci, 2012, 5: 8584

49 Hao J, Jiang Y, Gao X, et al. Functionalization of polybenzimidazole-crosslinked poly(vinylbenzyl chloride) with two cyclic quaternary ammonium cations for anion exchange membranes. J Membrane Sci, 2018, 548: 1-10

50 Sun P, Li Z, Wang S, et al. Performance enhancement of polybenzimidazole based high temperature proton exchange membranes with multifunctional crosslinker and highly sulfonated polyaniline. J Membrane Sci, 2018, 549: 660-669

51 Pan J, Chen C, Li Y, et al. Constructing ionic highway in alkaline polymer electrolytes. Energy Environ Sci, 2014, 7: 354-360

$52 \mathrm{Li} \mathrm{N}$, Yan T, Li Z, et al. Comb-shaped polymers to enhance hydroxide transport in anion exchange membranes. Energy Environ Sci, 2012, 5: 7888

Acknowledgements This research was supported by the National Natural Science Foundation of China (21720102003, 91534203 and 21522607) and the Fundamental Research Funds for the Central Universities (WK2060190072 and WK2340000066).

Author contributions $\mathrm{He} \mathrm{Y}$ and Zhang J designed the experiments; Zhang $\mathrm{J}$ and $\mathrm{He} \mathrm{Y}$ performed the experiments; Liang $\mathrm{X}$ and Ge $\mathrm{X}$ performed sample characterization;. Xu T, Wu L, Zhu Y, Hu M and Yang Z helped analyze the experimental data; Zhang J, He Y, and Wu L cowrote the manuscript with support from $\mathrm{Xu} \mathrm{T}$; all the authors contributed to the general discussion

Conflict of interest The authors declare no conflict of interest.

Supplementary information Experimental details are available in the online version of the paper. 

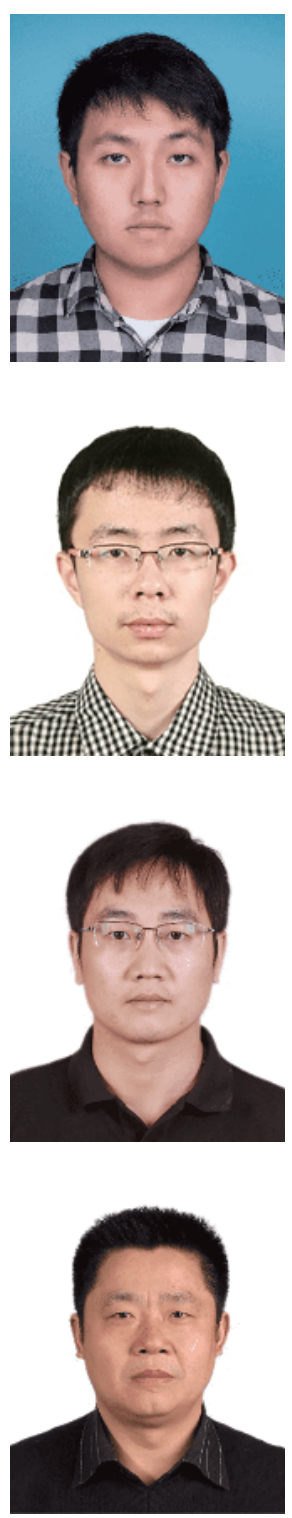

Jianjun Zhang received his BSc degree (2017) from Hefei University of Technology, and he is currently an MSc candidate at the University of Science and Technology of China (USTC). He is working on development of ion exchange membranes for fuel cells.
Yubin He received his BSc degree (2013) and PhD degree (2018) from USTC. His research interest mainly includes polyelectrolyte synthesis of the membranes for fuel cells, redox flow batteries and $\mathrm{Li}$ ion batteries.
Liang Wu received his BSc in polymer science and engineering from Hefei University of Technology in 2004, and his PhD in applied chemistry from USTC in 2009. He was a postdoctoral research fellow from 2009 to 2012 at USTC. He is currently a professor in the Department of Applied Chemistry at USTC. His research interest covers the development of ion exchange membranes for fuel cells and desalination.
Tongwen Xu received his BSc (1989) and MSc (1992) degrees from Hefei University of Technology and PhD (1995) degree from Tianjin University. He was a postdoctoral researcher at Nankai University (1995-1997). He was a visiting scientist at the University of Tokyo (2000), Tokyo Institute of Technology (2001) and Gwangju Institute of Science and Technology (2007). His research interest covers membranes and related processes, particularly ion exchange membranes for energy and environmental applications.

\section{基于亲核取代反应制备双离子侧链阴离子交换膜}

张建军 ${ }^{\dagger}$, 贺玉彬 ${ }^{\dagger}$, 梁铣, 葛晓琳, 祝渊, 胡敏, 杨正金, 吴亮 ${ }^{*}$, 徐铜文 ${ }^{*}$

摘要 作为碱性燃料电池的关键组分, 阴离子交换膜决定了其能量转化效率, 输出功率密度及长期稳定性. 最近, 带有双离子侧链的阴离子 交换膜, 因其良好的微相分离能力, 表现出了优异的离子电导率. 然而, 昂贵且复杂的合成方法限制了其商业化应用. 为了解决这一问题, 本文开发了一种简单、温和的合成方法. 首先通过亲核取代反应将叔胺前驱体引入到聚合物主链上, 避免了常用的氯/溴甲基化反应. 随 后与溴已基- $N, N, N$-三甲基铵进行简单的门秀金反应, 以高产率获得目标聚合物电解质. 所得到的阴离子交换膜表现出高的离子电导率, 良好的燃料电池性能以及有限的溶胀, 表明所提出的策略在燃料电池中具有应用前景. 